\title{
Environment and Consultation in the Brazilian Democratic Developmental State
}

\author{
Kathryn Hochstetler and J. Ricardo Tranjan \\ Forthcoming, Comparative Politics
}

\begin{abstract}
A Standard Research Grant from the Social Sciences and Humanities Research Council of Canada funded this research. We would like to thank Peter Kingstone, Alfred Montero, Almut Schilling-Vacaflor, and the anonymous reviewers for helpful comments on earlier versions of this manuscript. Thanks also to Mike Touchton and Brian Wampler for providing data.
\end{abstract}

Abstract: Twenty-first century developmental projects like those of the Brazilian Workers' Party take place in a regulatory context that - at least on paper - demands new scrutiny of their environmental and community impacts. Scholars of the democratic developmental state also argue that development now requires building human capabilities, promoting sustainable development, and seeking community feedback. We examine 302 electricity projects financed by BNDES to see if and when these developmentalist infrastructure projects faced challenging scrutiny on environmental and community impact grounds. Twenty-nine percent generated organized community opposition, extended licensing processes, and/or legal action. These were most common for large projects and ones where community and state actors worked together in blocking coalitions. We conclude that the ideals of the democratic developmental state are more compatible in theory than in practice. 
In the 1950s-1970s, the Brazilian developmental state built almost 100 large hydroelectric plants each decade. ${ }^{1}$ During the ensuing two decades while little new infrastructure was built, unprecedented regulatory models, norms, and actors were introduced both abroad and in Brazil; these demand greater attention to the impacts of infrastructure on environments and local communities. Under the Workers' Party (PT Partido dos Trabalhadores) administrations of Luiz Inácio Lula da Silva (2003-2010) and Dilma Rousseff (2011-), Brazil has now returned to having a developmental state that sets strategic plans and works with the private sector on economic projects that aim for accelerated growth. Electricity generation projects are among the most visible manifestations of the state's regained role. State planning and financing of electricity plants have increased installed electricity capacity since 2002. While critical for many of Brazil's economic goals, this expansion often, but not always, encountered challenges on socioenvironmental grounds. ${ }^{2}$ We focus on these projects to analyze how the twenty-first century version of the developmental state has adapted to new regulatory expectations. To what extent are large energy projects carried out differently now than they were in the earlier version of Brazilian developmentalism?

Brazil is not alone in these changes. After a generation of neoliberal economic reforms, it is just one of multiple countries that have returned to a larger state role in the economy. ${ }^{3}$ This shift has spurred interest in rethinking the developmental state in its twenty-first century manifestations. While maintaining a general understanding of a developmental state as an activist "master institution underlying both growth and welfare, $" 4$ this new literature asserts that different strategies should now be associated with developmental success. An important strand, which we build on here, stresses that in 
order to promote development, developmental states need to shift their focus from the industrial ambitions and actors of earlier developmentalism to instead seek to build human capabilities and address sustainability. These goals depend in turn on broad-based monitoring and feedback from civil society. ${ }^{5}$ We adopt the label "democratic developmental state" for this package of ambitions.

Global norms and regulatory models have evolved alongside academic theory. The US National Environmental Policy Act created the Environmental Protection Agency and introduced the idea of routine environmental impact assessment (EIA) with consultation of affected communities in $1969 .{ }^{6}$ The 1972 United Nations Conference on the Human Environment promoted these innovations and similar agencies and regulations spread around the world over the next decades, along with environmental movements. The World Bank, under pressure from activists, also began to reinforce these changes. ${ }^{7}$ The International Labour Organization also codified an indigenous collective right to prior consultation in its Convention 169 of 1989. Brazil's environmental institutions began comparatively early, in 1973, and EIA was added as a routine requirement in $1986 .{ }^{8}$ Communities also increasingly mobilize themselves to claim these rights in response to developmentalist projects. ${ }^{9}$ The net result of these changes is that twenty-first century developmentalist ambitions like those of the PT take place in a context that - at least on paper - demands new scrutiny of them based on socioenvironmental criteria. But how compelled are current developmentalist states to balance multiple development standards in practice? This article tackles this question by examining the frequency and nature of scrutiny faced by electricity plants built in Brazil since 2002 .

Rather than focusing only on well-known and highly contentious cases, such as 
big hydroelectric dams in the Amazon, ${ }^{10}$ we are concerned with understanding the socioenvironmental dimensions of a fuller range of projects. Under what conditions do responsible state agencies and/or mobilized citizens demand that environmental and community concerns be addressed in ways that suggest the new standards go beyond pro forma requirements? What do Brazil's recent experiences tell us about possible tensions in the ambitions of democratic developmental states? We use an original database of the 302 electricity generation loans contracted by the Brazilian National Economic and Social Development Bank (BNDES, Banco Nacional de Desenvolvimento Econômico e Social) between 2002 and 2012 to address these questions. ${ }^{11}$

\section{The Twenty-first Century Developmental State and Its Project Siting Dilemmas}

We join three theoretical literatures that are rarely considered together. One is the literature on the developmental state, which makes claims about the state qualities that are necessary for economic development. The second is the literature on environmental governance, which identifies environmental impact assessment and environmental movements as critical oversight mechanisms for sustainable development. The third literature, on the politics of siting projects, offers arguments about when communities are likely to become actively involved in contention around projects.

The concept of the developmental state began with Chalmers Johnson's study of Japan's economic expansion and later expanded geographically. ${ }^{12}$ It is defined by state intervention that is technocratically oriented towards the long-term development needs of the economy, even determining which industries should rise and fall. The state takes primacy over private actors through strategies like indicative planning and monitoring by bureaucrats and offering incentives to market actors. ${ }^{13}$ While most states, developmental 
and not, confront the new expectations that they will consider environmental impacts and consult with affected communities, ${ }^{14}$ the centrality of the state in the developmental state's economic model makes potential socioenvironmental conflicts focus directly on the state rather than on private firms. The classic developmental state was also associated with industrialization. This was supported with policies that included protection of infant industries, creation of state owned firms, and infrastructure development. ${ }^{15}$

Analyses of recent developmentalism have identified multiple changes in what twenty-first century developmental states should and actually do to promote development. One line of analysis, which often calls its model "neo-developmentalism," has focused on current developmentalism's roots in both traditional developmentalism and the Washington Consensus. From the first it takes a structuralist orientation that prescribes state activism, full employment, and outward facing economic nationalism with support for innovation and competitiveness; from the latter come commitments to macroeconomic stability and international openness. ${ }^{16}$ Among the Brazilian policies that most clearly embody neo-developmentalist strategies is the growth in public investment in infrastructure - including electricity - that was largely financed by the state ${ }^{17}$ Such projects form our empirical focus here.

Theoretically, however, we contribute more to a second line of analysis of the twenty-first century developmental state that sees sharper discontinuities with traditional theorizing about development: development in this view is now about states' role in developing human capabilities, which developmental states should do by working with civil society to provide services like health and education. ${ }^{18}$ As presented by Peter Evans - a long time scholar of developmentalism in Brazil - and Patrick Heller, this shift comes 
from theoretical updating about the sources of development. It reflects the arguments of Amartya Sen and others that developmental success now requires building human capital so that citizens can take part in the idea- and innovation-driven global economy. Given that aim, and just as older developmental states had to be autonomous but also embedded in the industrial sectors they were guiding, the new developmental state now depends on participation by organized civil society to co-produce outcomes and provide feedback that improves service delivery. ${ }^{19}$ Similar prescriptions also come from scholars who start instead with the puzzle of how a fully democratic developmental state would function. ${ }^{20}$ Because of this, and the participatory dimensions of Evans and Heller's model, this conception of modern developmentalism is often referred to as the democratic developmental state.

The themes of this article - environmental protection, community consultation, and electricity - are considered in the democratic developmental state literature to be either priority areas for reform ${ }^{21}$ or ones that will facilitate achievement of the capability aims. Electricity is a very basic service, of course, powering lighting, computers, medical devices and many of the other physical tools of both health and education. Community consultation is critical for channeling feedback to states to insure that state action is effective and creates outcomes citizens value; civil society actors are also co-producers of many education, health, and environmental outcomes. ${ }^{22}$ These ideas stand in stark contrast to how the classic developmental state theorists and policy makers thought of the environment and citizen consultation.

The classic developmental state - and its academic literature - operated in a historic moment when environmental considerations were sometimes raised in protests, 
but not yet considered routinely. Most developmental states of the twentieth century aimed for industrialization, which has notoriously negative consequences for resource exhaustion and pollution. ${ }^{23}$ The bureaucrats who guided developmental states were clustered in financial and trade ministries, not environmental ones. Yet there are, in principle, openings for environmental concerns in the developmental state's focus on long-term development needs, even if early developmentalists rarely weighed them. Environmental costs are often only apparent in a long time frame. Meanwhile, green technologies are increasingly seen as the future growth industries. ${ }^{24}$ Given this hypothetical possibility that environmental concerns could be brought more fully into the developmental state's ambitions, it is important to consider how that might happen.

National environmental agencies and legislation have spread quickly around the world since 1969. EIA has become the most widely adopted environmental regulation worldwide and the most important one for systematically evaluating the environmental implications of economic projects. ${ }^{25}$ In the standard EIA process, firms prepare reports of the environmental impacts of a proposed economic activity, consider available alternatives, and propose ways to ameliorate or compensate for the impacts. State actors then evaluate the firm's assessment and may license the project, request changes, or reject it. With state agencies active in planning, financing, and often executing projects, EIA thus potentially pits one part of the developmental state against another. Regulatory failures are common in clashes of this kind, especially in the Global South. ${ }^{26}$

The fit between citizen consultation and contention and the normative framework of the developmental state is even more problematic. On the one hand, its classic theorists assumed that a well-functioning developmental state would consider broad national 
interests while community opposition almost always originates in perceptions of concentrated local costs. ${ }^{27}$ Citizen inclusion in decision-making was thought to harm national outcomes since hampered the state's focus on industrial expansion. ${ }^{28}$ On the other hand, Brazilian EIA and its consultative processes have been lauded as one of a set of participatory initiatives that prevents industrial interests from dominating the policy arena. ${ }^{29}$ Scholars of the democratic developmental state argue that while states now need to take time to persuade citizens, development results may be more legitimate and effective..$^{30}$ In addition, the brakes on economic expansion might be compensated by long-term environmental sustainability gains.

The question of development outcomes is too large for this article. However both sides of the argument agree on an empirical assumption that we can evaluate as a first step: civil society does mobilize around its interests in development projects, on its own or with state actors. Existing research on the politics of siting energy projects concludes that civil society responses are among the most critical determinants of whether they can be built as planned. ${ }^{31}$ With their "site fights" communities can potentially block projects or reorient entire segments of the energy industry. Whether or not civil society mobilizes may appear to have an obvious answer. Both the news media and the academic literature present many stories of contestation. ${ }^{32}$ Much of the research on social contestation shares the fundamental methodological problem of having selected cases for study because there is mobilization, however. The baseline level of collective action - how much engagement there is in situations that might warrant it - is largely unknown. ${ }^{33}$

Our research strategy for addressing these issues is developed in the remaining sections of this article. We present a study of how environmental and local community 
concerns were introduced into recent (2002-2012) electricity projects in Brazil, analyzing which of these projects encountered resistance. We call instances of resistance "challenges" and identify them by evidence that: local communities sought to block projects or demanded changes in their implementation; EIA processes were long or conflictual; or legal challenges were brought by the Ministério Público (MP or Public Ministry, a public defender's office discussed below $)^{34}$ on environmental or community impact and/or compensation grounds. Such challenges are indications of tensions within recent Brazilian developmentalism. If they are frequent, the implication is that democratic developmental states will find it difficult to reconcile all their aims. Drawing on the literatures already discussed, we consider three sets of potential explanations for such challenges.

The first is the overall level of risk represented by the project. This set of explanations recognizes that electricity types have different characteristic risks and benefits for the environment, health, property values, and the like. Hydropower and wind power plants, for example, must be built in particular locations that have appropriate geophysical characteristics, like rapidly running water and windy areas (often coastal). Since these characteristics are associated with human settlements, the projects are likely to have direct local impacts. Brazil's remaining sites for large-scale hydropower are in the Amazon region, ${ }^{35}$ so such projects will inevitably have large-scale environmental costs from deforestation and other environmental impacts. ${ }^{36}$ Nuclear plants have less immediate impacts, but carry risks of catastrophic failures and problems with the storage of radioactive materials. ${ }^{37}$ Fossil fuel plants pair low immediate socioenvironmental impacts with implications for global warming. ${ }^{38}$ Each electricity type also offers distinct 
ancillary benefits, e.g., for employment. This set of possible explanations for responses to particular electricity projects is most compatible with the traditional developmental state, as they concern costs, benefits, and risks that will affect development outcomes and can be technically evaluated.

The next two sets of explanations reflect the fact that there is rarely a direct relationship between problems and contestation. Weak challengers will be unable to muster serious opposition even to projects that will cause harm. The political opportunity variables focus on the presence of allies that can offer strategic support to challengers. ${ }^{39}$ For example, the fact that communities can take their environmental claims directly to the Ministério Público that then - for free - will investigate and possibly charge developers with infractions is a significant opportunity for communities that did not exist in the big dam period in Brazil. ${ }^{40}$ Finally, the community context variables look to community characteristics to explain the presence or absence of challenges, including experience with a similar industry, a history of oppositional action, or economic hardship. ${ }^{41}$ Other scholars have charged that states are sensitive to such community contexts, choosing to locate potentially hazardous infrastructure projects in communities that are likely to be too weak to resist. ${ }^{42}$

Following an overview of the processes and actors surrounding electricity projects in Brazil, we present the results of a statistical analysis of these three sets of variables, and discuss which of them best fit with the patterns of resistance to energy projects found in Brazil.

\section{Electricity in Brazil: Processes and Actors}

In Brazil, electricity generation projects for the national grid are planned, selected, 
and largely financed by the state. Brazil thus offers an opportunity to examine statesociety relations in the electricity sector of a developmental state where long-standing economic institutions now face new expectations about considering environmental and community impacts. In this section, we offer a brief introduction to the processes and actors involved.

In the 1990s, the Cardoso administrations (1995-2002) partially privatized the national electricity system that had been under state control through Eletrobras since the earlier developmentalist period. ${ }^{43}$ A new independent regulator, ANEEL (Agência Nacional de Energia Elétrica, National Electricity Agency), holds auctions for licenses for public and private generation firms to supply electricity to the national grid. Each of the projects in our database has won such an auction to supply electricity from a new installation. The single national grid and the centralized procurement system effectively nationalize the generation side of Brazilian electricity. Widespread electricity blackouts in 2001 led the Cardoso administration to contract new projects in its last year in office. These are the first cases in our dataset, but most were developed under the democratic developmental state of Lula and Rousseff.

In 2004, Lula's government created the Energy Research Enterprise (EPE Empresa de Pesquisa Energética), a semi-autonomous planning and research agency that plays many of the roles Eletrobras once did. Many of EPE's activities match the classic model of the developmental state in that it is a technocratic bureaucracy that carries out indicative planning for the economy. Among its most important projects is an annual assessment of the Brazilian electricity sector, ${ }^{44}$ which feeds into longer-term documents that lay out plans for expansion in the sector. ${ }^{45}$ These plans are essentially optimization 
exercises, which use extensive data - on physically appropriate sites, economic dynamics, existing installations, likely energy demand, carbon emissions, and more - to generate lists of new electricity plants to be built. ${ }^{46} \mathrm{EPE}$ has a strong technical corps. Most have advanced degrees and have gone through the stringent public competition process. ${ }^{47}$ In addition to planning, they also gather baseline data and help guide firms through the bidding and licensing processes.

EPE planning has not fully driven state electricity initiatives. Early wind and small hydropower projects also responded to the Program of Incentives for Alternative Energy in Electricity (Proinfa - Programa de Incentivo às Fontes Alternativas de Energia Elétrica).$^{48}$ Other projects were part of the Growth Acceleration Programs (PAC 1 and 2, Programa de Aceleração do Crescimento). ${ }^{49}$ These projects were selected by an inter-ministerial group to generate short-term stimulus. Under Rousseff, PAC administrators have set up dozens of "Situation Rooms" (Salas de Situação) that bring together high-level representatives of government agencies to discuss how to work out the bottlenecks (gargalos) that have blocked quick implementation of PAC projects. There are permanent Situation Rooms for the Belo Monte and Santo Antônio hydroelectric dams, while other installations acquire them when there are problems. ${ }^{50}$

The federal government is also involved in financing many of these electricity projects through BNDES, the primary source of long-term finance for major economic projects since its creation in $1952 .{ }^{51}$ In the 1990s, BNDES presided over the privatization of the electricity generation sector; the Lula administration greatly increased its funds after 2005 and made it a central actor in the renewed developmental state. ${ }^{52}$ The project finance modality has been used for about 300 BNDES energy loans since 2004, with only 
one non-performing loan. ${ }^{53}$ Our focus here is on project-level challenges, but BNDES also faces general pressure from civil society activists over its lack of regard for the community and environmental impacts of the projects it finances. Bank activists switched their attention from the World Bank to BNDES in the mid-2000s, as international lending dropped while BNDES' surged. The Plataforma BNDES network has monitored the socioenvironmental impacts of BNDES' activities ${ }^{54}$ although the bank sees these as considerations best left to experts in the environmental licensing agencies. ${ }^{55}$ In any event, BNDES finances projects but does not decide which will be built.

Environmental considerations enter into the generation process most directly through environmental licensing, first regulated nationally in Brazil in 1986. Brazilian environmental agencies took more than a decade to develop their capacity to carry out such assessments, and capacity is still uneven across Brazil's subnational units. ${ }^{56}$ IBAMA, an agency of the federal Ministry of Environment, licenses plants sited in more than one state, in frontier and coastal zones, or in indigenous and conservation areas, as well as projects expected to have a large environmental impact. Otherwise, state-level environmental agencies are responsible for licensing. ${ }^{57}$

To build an electricity plant, firms first have to obtain a preliminary license, which requires the actual Environmental Impact Study (EIS) and a simplified version in lay language. The latter must be publicly available and legislation encourages it to be presented to local communities in public audiences. The subsequent installation license must include a Basic Environment Plan describing resettlement programs and mitigation measures. These documents are legal contracts against which future actions will be assessed. After this license, construction work may begin. The operation license is the 
last step before the turning on of the plant; its issuing depends upon the fulfillment of the previous commitments. Unusually long and contentious licensing processes may occur as a result of the probing of licensing agencies, sometimes acting on their own initiative, and sometimes acting under by others. Even routine licensing considers socioenvironmental impacts and demands compensation and mitigation of them, to an extent decried by the World Bank. ${ }^{58}$ In the Situation Rooms, licensing "bottlenecks" are frequently alleged, even as activists find the procedures hasty. ${ }^{59}$

The flourishing of the Ministério Público (MP) has also influenced electricity decision-making. This actor has the power to carry out investigations and may bring legal charges against any actor in the public or private sector that it believes is violating collective societal interests. It is obligated to follow up on citizen complaints and may initiate its own investigations. ${ }^{60}$ The very active state-level MP in São Paulo investigated almost 37,000 cases from $1984-2004 ;{ }^{61}$ while the MP in other states is less active, the federal MP often picks up the slack. All participants in the impact assessment process understand that their actions are subject to the close oversight of the MP.

Below, we group actions of environmental licensing agencies and the MP together as state-based challenges to the planned electricity projects of the Brazilian developmental state. Despite the institutional independence of the MP, it is empirically difficult to disentangle the work of these two sets of institutions. The MP typically acts by challenging the validity of licensing processes, which inevitably complicates and delays cases, and long and complicated licensing cases always draw the attention and scrutiny of the MP. From the standpoint of social movements, the MP forms a blocking coalition with them while the environmental agencies stand separate. ${ }^{62}$ From the 
standpoint of the economic agencies central to developmentalism, however, the licensing agencies and MP together form a state-based bottleneck for many infrastructure projects. $^{63}$

Local communities rarely contested the original developmental state's electricity projects. Since Brazil returned to democracy in 1985, however, local organizing is much more common. It tends to be focused on socio-economic impacts and compensation, but also sometimes concerns environmental impacts. Local communities may gain support from national and international organizations. One frequent supporter is the grassroots based Movement of Dam-Affected People (MAB, Movimento dos Atingidos por Barragens). ${ }^{64}$ The environmental justice movement also took steps in the 2000 s to try to ensure that firms did not simply relocate projects from densely-mobilized to lessmobilized parts of Brazil by setting up networks that provide legal and organizational assistance to local communities. ${ }^{65}$ During the military period, foreign non-governmental organizations (NGOs) played a large role in helping Brazilian communities fight some large projects, and they have continued to be present and active, if less central now that Brazil primarily finances its own energy and infrastructure projects through BNDES.

This section has shown that Brazil has institutions, actors, and regulations that embody aims like those indicated in the theoretical literature on the democratic developmental state. Some state institutions plan, fund, and execute electricity infrastructure projects. Other actors - inside and outside the state - monitor and evaluate the impacts of those projects on the environment and local communities. There are mechanisms for consultation and communities may also organize themselves. Next, we show how those interact in a large set of recent electricity projects. 
Table 1. Electricity projects by number and number of challenges

\begin{tabular}{lccc}
\hline Type of project & $\begin{array}{c}\text { Total number } \\
\text { of projects }\end{array}$ & $\begin{array}{c}\text { Civil society } \\
\text { contention }(\% \\
\text { challenged) }\end{array}$ & $\begin{array}{c}\text { State action against } \\
\text { project (\% } \\
\text { challenged) }\end{array}$ \\
\hline $\begin{array}{l}\text { Wind power plant } \\
\begin{array}{l}\text { Small (under 30 MW) } \\
\text { hydroelectric power plant }\end{array}\end{array}$ & 138 & $21(15.2)$ & $11(8.0)$ \\
$\begin{array}{l}\text { Large hydroelectric power } \\
\text { plant (over 30 MW) }\end{array}$ & 109 & $22(20.2)$ & $22(20.2)$ \\
$\begin{array}{l}\text { Fossil fuel power plant (oil, } \\
\text { diesel, gas) }\end{array}$ & 13 & $17(41.5)$ & $23(56.1)$ \\
$\begin{array}{l}\text { Nuclear power plant } \\
\text { All projects }\end{array}$ & 1 & $1(7.7)$ & $3(23.1)$ \\
\hline
\end{tabular}

Source: Calculated by the authors from BNDES data on electricity project loans and author research on challenges to particular electricity projects, as detailed in the text.

\section{Electricity Expansion in the Twenty-First Century Developmental State}

Our study focuses on projects to generate electricity for the national grid, as exemplified by BNDES' loan contracts from 2002-2012. Table 1 shows that BNDES contracted 302 loans for new electricity plants during this decade. We constructed an original dataset of such loans using BNDES' online press releases and annual summaries of all BNDES lending in the industry and infrastructure sectors that we acquired through a Freedom of Information request to the Bank. ${ }^{66}$ Small hydroelectric plants (109) and wind power plants (138) received the largest number of contracts in our dataset (247 of 302). Despite being $82 \%$ of the total number of electricity contracts, they added up to less than 20 percent of the total value of the loans contracted during this time and only $13.8 \%$ of the total installed capacity. The single largest loan in the dataset, for the Belo Monte hydroelectric dam, was considerably more than all of the wind and small hydro projects together and ultimately may generate less electricity annually than their total. 
Table 1 also shows that most electricity projects were built without substantial opposition from mobilized civil society, a legal challenge from the Ministério Público, or a contentious environmental licensing process - well below what headlines might suggest. Taking account of the projects that faced challenges from more than one kind of actor, we found that 71 percent of the projects were built without any reported opposition on environmental or community impact grounds. On the other hand, even projects that were not challenged underwent EIA processes and required consultation with local communities about impacts. The next section examines some of the correlates of more challenging scrutiny of individual electricity projects and explains how we generated our counts of challenges.

\section{Accounting for Challenges to Brazilian Electricity Projects: Data, Measures, and Analysis}

We have three families of expectations of when challenges to electricity projects might occur: in response to project risks, the political opportunities that potential challengers have, and the characteristics of project host communities. To evaluate these arguments, we present a quantitative analysis of the factors that might account for challenges to electricity projects by host communities or by state actors (the licensing agencies and/or the MP), the dependent variables in two separate analyses. The analysis begins in 2002 and concludes in 2012, and includes 302 electricity projects funded by BNDES. Because of the binary nature of the dependent variables, we employ logistic regression analyses of the existence of challenges, using the variables identified in the next paragraphs and including robust standard errors.

Dependent variables: local community challenges and state challenges: The first 
dependent variable captures whether local communities succeeded in calling public attention to their cause. We identified community challenges by searching news sources to find evidence that local communities sought to block projects, demand changes in their implementation, or denounce social injustice or environmental negligence in the EIA process. Collecting such newspaper-based data is a common strategy for quantitative study of collective action. ${ }^{67}$ Specific tactics communities used included the occupation of construction sites, roadblocks, coordinated participation in consultation processes, collaboration with scholars, and collective lawsuits. We used a similar strategy to identify our second dependent variable: state challenges were identified by EIA processes that were conflictual enough to merit news coverage or legal investigations conducted by the Ministério Público. When state interventions result in the suspension of licenses and the interruption of construction works, which they commonly do, media attention is almost certain. We counted any mention of active resistance to a project by any of these actors, but did not include simple statements of opposition by individuals.

All such challenges were identified through full-text manual searches using the name of the electricity project in the electronic archives of the Folha de São Paulo and Globo newspapers and the websites of federal and state-level MP offices and environmental agencies, when available. We also searched one state-level newspaper, seeking less visible mobilization that nevertheless succeeded in calling regional attention to claims. Finally, we consulted websites of activist organizations that maintain records of challenges to BNDES' lending or electricity projects. Technical risk factors: Electricity fuel sources present different levels of environmental and other risks, as well as varying constellations of costs and benefits to local 
communities and national economies. We capture these by examining the extent to which challenge rates vary by the type of electricity plant being built. In the analyses below, large hydropower plants (more than $30 \mathrm{MW}$ installed capacity) are used as the reference category, as these have historically been the baseload of the Brazilian electricity system. ${ }^{68}$ Other types are nuclear, small hydro, wind, and fossil fuel power plants.

Beyond risks that are captured by the differences between fuel types, technical project risk also varies by the size and clustering of projects. Whatever the fuel type, larger plants have larger impacts. Therefore we include a variable for the installed capacity, in megawatts (logged), of each project. (Data on the projects' installed capacity is from BNDES.) Studies also show that multiple small projects that are closely clustered together can have cumulative impacts that rival those of single large projects. ${ }^{69} \mathrm{We}$ include a dummy variable that takes on the value of 1 when projects are clustered on the same river or municipality. We expect that the potential cumulative impact should generate challenges to new projects.

Since such technical risk factors are within the purview of a developmental state's consideration of long-term growth prospects, we conduct an initial analysis of challenges using only these variables (Models 1 and 2), before analyzing a more-fully specified model. We expect the directions of any potential effects of risk to be the same for all actors.

Political Opportunity Variables: The political opportunity approach has been stretched to cover many possible variables. ${ }^{70}$ Here, we draw on its core insights, which ask whether potential challengers receive support or pressure from key allies that move them to act. Such support might be institutionalized, as with the relationship between EIA and 
affected communities, while other support is more contingent, depending on electoral outcomes or the mobilization of related groups.

Here, we consider that the activities of local communities and state actors might each potentially affect challenges by the other. For local communities, investigations and court cases brought by the MP may increase the odds of resistance, since a powerful actor has also signed on to challenge the project. Similarly, if environmental agencies are conducting a protracted licensing process, local communities will have more time to organize and add their concerns to the process. Conversely, local communities may trigger investigations by the MP. Community input into public EIA consultations may spur further questioning and additional changes requested in the licensing process. In the estimations below, then, challenges by state actors are one of the possible correlates of challenges by local communities, and vice versa.

The media searches described above were also used to find evidence of whether national or international NGOs mobilized to influence the design or even termination of particular electricity projects. They could positively influence the response of both community and state actors, providing elite support for communities, activating the MP, or pressuring environmental licensing agencies.

Finally, we take note of whether the mayor of the municipality that will site a project is of the PT. The party held the national executive for nearly this entire time period, and thus controlled national electricity processes. This association of projects and national party leads us to expect that PT mayors will be more likely to support execution of a project in their municipality. Earlier research has shown that local officials in Brazil can affect how quickly environmental licenses are approved, ${ }^{71}$ so there should be fewer 
licensing challenges under PT administrations. There is an additional link between firms' campaign donations to PT candidates and the firms' access to public works contracts that could potentially spill over to affect outcomes in the cases we consider, but too few such donations were made in our cases to include them in our analysis. ${ }^{72}$

Earlier research on the relationship between a PT mayor and community mobilization is mixed. The PT has historically had close ties with social movements and acceptance of grassroots mobilization is one of the hallmarks of PT partisanship, ${ }^{73}$ suggesting PT administrations may be more supportive of community mobilization. On the other hand, social movements have self-limited their mobilizations during PT administrations, suggesting a negative relationship. ${ }^{74}$ Data on mayoral partisanship is from the Supreme Electoral Tribunal. ${ }^{75}$

Community Context Variables: Finally, communities themselves vary in ways that may affect their ability and willingness to mobilize. Small, poor communities are more likely to lack the capacity to mobilize and more likely to value whatever economic benefits may come from the construction of infrastructure in their municipality ${ }^{76}$ with both dynamics reducing challenges. The likely lower levels of pressure from poor communities also make state actors less likely to challenge projects on their behalf or may even, as environmental justice arguments claim, make state actors prefer these locations for development projects. ${ }^{77}$

Most community development indicators in Brazil are highly correlated. Largepopulation municipalities have large economies and high levels of social organization, even on a per capita basis. We use three measures of community development that are not strongly correlated: the number of NGOs per 1000 people, GDP per capita, and the UN's 
Human Development Index, all measured at the municipal level. All economic data are from Brazil's public statistical agency, the Brazilian Institute of Geography and Statistics (IBGE, Instituto Brasileiro de Geografia e Estatística). ${ }^{78}$ Population and GDP figures would often be used as control variables in models of this kind, but were highly correlated with the community variables we used, so were not included. Substituting them produced similar results.

\section{Results}

Table 2 presents the results of four estimations. Models 1 and 2 estimate the influence of just the technical risk factors on local community and state challenges, respectively, to electricity projects. The first variables measure whether electricity projects of different fuel types face more or fewer challenges than the reference large hydropower category (the single nuclear installation is perfectly predicted, so drops out of the analysis of both models). Local communities and state actors respond similarly to the technical risk factors. Larger projects of all fuel types are more likely to generate challenges in all the models, the only variable for which this is true. Both communities and state actors continue to make significantly more challenges to larger projects once a broader set of political opportunity and community variables are included. At the same time, the cumulative impact of multiple small projects is not associated with challenges in any of the models. In three of the four models, challenges to fossil fuel plants are less likely than are challenges to the reference large hydropower cases. Once other variables are included, small hydro and wind projects face more challenges from communities than do large hydro plants, suggesting that communities may object to such projects for reasons other than their size. 
Table 2 Results of Logit Estimation of Challenges by Local Communities and State Actors

\begin{tabular}{|c|c|c|c|c|}
\hline & $\begin{array}{l}\text { Model } 1 \\
\text { Basic level of } \\
\text { risk model for } \\
\text { community } \\
\text { challenge }\end{array}$ & $\begin{array}{c}\text { Model } 2 \\
\text { Basic level of } \\
\text { risk model for } \\
\text { state-based } \\
\text { challenge }\end{array}$ & $\begin{array}{c}\text { Model } 3 \\
\text { Full model for } \\
\text { community } \\
\text { challenge }\end{array}$ & $\begin{array}{c}\text { Model } 4 \\
\text { Full model for } \\
\text { state-based } \\
\text { challenge }\end{array}$ \\
\hline Small hydro & $\begin{array}{l}1.1367 \\
(.7846)\end{array}$ & $\begin{array}{l}.7109 \\
(.8354)\end{array}$ & $\begin{array}{l}\text { 3.0516* } \\
(1.4983)\end{array}$ & $\begin{array}{c}.5766 \\
(1.0018)\end{array}$ \\
\hline Wind & $\begin{array}{r}.7383 \\
(.7385) \\
\end{array}$ & $\begin{array}{r}-.3464 \\
(.7959) \\
\end{array}$ & $\begin{array}{l}2.7874 \% \\
(1.3992)\end{array}$ & $\begin{array}{l}-.0102 \\
(.8131)\end{array}$ \\
\hline Fossil fuel & $\begin{array}{l}-2.8030 * \\
(1.1210)\end{array}$ & $\begin{array}{c}-2.5044 * * \\
(.7987)\end{array}$ & $\begin{array}{c}.0991 \\
(1.5026)\end{array}$ & $\begin{array}{c}-\mathbf{- 3 . 4 8 1 5 * *} \\
(1.0723)\end{array}$ \\
\hline $\begin{array}{l}\text { MW installed } \\
\text { (logged) }\end{array}$ & $\begin{array}{c}2.0721 * * \\
(.5793)\end{array}$ & $\begin{array}{c}2.5090 * * \\
(.7092)\end{array}$ & $\begin{array}{c}1.8062 * * \\
(.7050)\end{array}$ & $\begin{array}{c}2.4917 * * \\
(.9722)\end{array}$ \\
\hline Multiple plants & $\begin{array}{l}-.3224 \\
(.3768) \\
\end{array}$ & $\begin{array}{l}-.5888 \\
(.4359)\end{array}$ & $\begin{array}{c}.0409 \\
(.4956)\end{array}$ & $\begin{array}{l}-.6890 \\
(.4704)\end{array}$ \\
\hline PT mayor & & & $\begin{array}{l}1.4819 * \\
(.6187) \\
\end{array}$ & $\begin{array}{c}-3.0429 * * \\
(1.0804) \\
\end{array}$ \\
\hline State challenge & & & $\begin{array}{c}1.6895 * * \\
(.6589)\end{array}$ & \\
\hline $\begin{array}{l}\text { Community } \\
\text { challenge }\end{array}$ & & & & $\begin{array}{c}1.6946 * * \\
(.6022)\end{array}$ \\
\hline $\begin{array}{l}\text { Civil society } \\
\text { allies }\end{array}$ & & & & $\begin{array}{l}1.1501 \\
(.9318)\end{array}$ \\
\hline $\begin{array}{l}\text { NGOs per } 1000 \\
\text { people }\end{array}$ & & & $\begin{array}{c}.0634 \\
(.0435)\end{array}$ & $\begin{array}{l}-.2591 \\
(.1336)\end{array}$ \\
\hline GDP per capita & & & $\begin{array}{l}.000019 \\
(.000015)\end{array}$ & $\begin{array}{l}.000020 \\
(.000013)\end{array}$ \\
\hline HDI & & & $\begin{array}{c}\mathbf{- 8 . 4 7 2 0}^{* *} \\
(3.2880)\end{array}$ & $\begin{array}{c}3.4374 \\
(3.4651)\end{array}$ \\
\hline Number of obs. & 301 & 301 & 275 & 299 \\
\hline Wald chi2 & 25.90 & 45.03 & 23.18 & 53.04 \\
\hline Prob $>$ chi 2 & 0.0001 & 0.0000 & 0.0101 & 0.0000 \\
\hline Pseudo R2 & 0.1036 & 0.2164 & 0.1501 & 0.3873 \\
\hline
\end{tabular}

Notes: Robust standard errors are in parentheses. *significant at $0.05 ; * *$ significant at 0.01 .

Beyond size, the political coalition variables take center stage for analyzing both kinds of challenges. For communities (Model 3), the presence of civil society allies predicts the existence of challenges perfectly, and so is dropped from the statistical 
estimation. State action also significantly and positively correlates with mobilization by local communities, as does having a PT mayor in office. State actors (Model 4) also seem sensitive to the presence or absence of categories of actors. State actors are responsive to the engagement of local community - but not national or international - civil society actors. While the presence of a PT mayor is also significantly correlated with state challenges, the relationship is now signed negative, as expected, meaning that state actors are less likely to challenge projects where local and national partisanship line up. Thus community and state challenges move in opposite directions when local political leaders share partisan alliances with the national PT government. None of the community context variables reach statistical significance, although the density of NGOs nearly does.

\section{Discussion of Results}

Above, we identified three families of explanations for when resistance to specific electricity projects might appear. One explanation focused on the risk profile of the project, suggesting that the type of fuel or scale of physical impact - from a large plant or the cumulative impact of multiple small ones - might affect how much scrutiny the project receives. A second, political opportunity, argument suggests that host communities and state actors would be more likely to challenge projects if they found allies and institutions to support them. Finally, the community context explanations look to characteristics of the host community to explain the presence or absence of resistance to projects.

One of the clearest results of our quantitative analysis is that larger projects are substantially more likely to generate resistance, a result that holds in all the models, whether other variables are present or not. This is not surprising, since size is a 
particularly visible marker of impact. The results here also support previous case study research that argues that some kinds of risk are often overlooked. ${ }^{79}$ For example, the cumulative effect of multiple plants is not associated with more challenges even though they can be equally damaging. In addition, the easiest projects to build without opposition are the fossil fuel plants, which emit the most greenhouse gases. In fact, once size and other variables are accounted for, local communities are most likely to challenge the wind and small hydropower plants often favored by climate activists. Thus challenges do appear to be focusing on local and near-term impacts rather than long-term ones.

Our results also support previous conclusions that much of Brazilian environmental policy making takes place through informal coalitions of state and societal actors that mobilize networks to either block or enable particular outcomes. ${ }^{80} \mathrm{We}$ find that state actors are more likely to scrutinize electricity projects through lengthy EIA processes and/or legal challenges if community activists are also active - and vice versa. We cannot distinguish the direction of the relationship in our quantitative study, but the qualitative studies cited in this article indicate that blocking coalitions often begin with community activists and the MP in a coalition, which subsequently challenges and lengthens the licensing process. This fits the pattern of many mobilizations around large hydropower including the well-known Belo Monte case.

We do not find that community-level variables are associated with levels of opposition to electricity projects. This finding goes against the expectations of environmental justice scholars and deserves additional research. With the MP and national activists as potential allies and the licensing process as a point of access, many communities can apparently organize at least to affect implementation. ${ }^{81}$ For example, 
river communities have been able to draw on $\mathrm{MAB}$ and other national and international activists in support of their challenges; MAB has subsidiary organizations in seventeen of Brazil's twenty-seven subnational units. ${ }^{82}$ It is also possible that some communities may favor the projects for reasons we have not explored here.

On balance, our quantitative study reinforces existing qualitative research on Brazilian socioenvironmentalism. Big electricity projects do generate more frequent challenges, although they should not obscure the many times communities also resist implementation of seemingly innocuous wind and small hydropower plants - or fail to mobilize at all. Blocking networks are often built across the state-society divide, challenging other parts of the state that are promoting projects. Exploring a similar question with a different kind of data and analysis is an important triangulation strategy that should generate greater confidence in both sets of results when the evidence and conclusions are compatible, as they are here.

\section{Conclusions}

Theorists of the democratic development state hold that it is possible and even necessary for such states to join the ambitious indicative planning and activism of the classic developmental state with new attention to building human capabilities, consultations with civil society, and environmental sustainability. This study of recent electricity projects in Brazil attempts to empirically evaluate how well the Brazilian developmental state since 2002 has managed the evident tensions between those ambitions. To what extent are large energy projects carried out differently now than they were in earlier versions of Brazilian developmentalism?

The current Brazilian developmental state - and other states, developmental and 
not - clearly faces more scrutiny of its development choices than did the state of the 1940s and 1950s. ${ }^{83}$ Since 1986, all projects undergo environmental impact assessment, a process that can be both long and stringent. The Ministério Público is poised to legally challenge projects that take short cuts, and backs up newly active community and civil society actors who are attuned to the impacts of projects on their communities. Together these do introduce routine consideration of environmental and community impacts. In 71 percent of the projects we study, we find that this process happens without additional newsworthy challenges. Our analysis shows that these tend to be smaller wind and hydropower projects where potential opponents do not find active allies. Others are projects whose hazards are long term and abstract, like fossil fuel plants and their climate change effects, rather than immediate and local. The characteristics of the local communities do not affect how likely they are to mobilize. We know very little about these routine projects, including how close they come to the ideal of capabilities-building, sustainable development. ${ }^{84}$

Most of the existing secondary literature is on the 29 percent of the cases (especially the Belo Monte hydroelectric dam) where local and national activists, the Ministério Público, and environmental licensing agencies form complex coalitions that can significantly alter and delay particular projects. News sources and the planning and financing agencies of the state pay particular attention to these cases and Situation Rooms have been set up to push them forward. It is worth noting that only one of the 302 projects considered here has been set aside altogether. State and societal actors have some ability to shift the exact location and character of project impacts and to insist on compensation for impacts that are not avoided. But they have little ability to stop projects 
altogether, and the planning process is one that finds the megawatts of electricity needed somewhere ${ }^{85}$ with some impacts on some community and some environment. This article shows that just when and how those impacts occur is most importantly affected by the ability of state and societal actors to jointly mobilize to directly challenge a project, a process that happens quite unevenly.

Putting together the stories of routine consideration of socioenvironmental impacts and the more complex picture of the contentious projects, we conclude that this time is different. That is, environmental and community impact considerations play significant roles in the post-2002 Brazilian developmental state that they did not in earlier Brazilian developmentalism. At the same time, the ongoing high levels of conflict over many electricity projects support the worry that the ideals of the democratic developmental state are easier to fit together in theory than in practice. ${ }^{86}$ The underlying ideals themselves are complex. For example, environmental sustainability involves both immediate socioenvironmental impacts and also long-term environmental effects like climate change, but individual electricity projects may do well on one and badly on the other. Creating institutions and ties to citizens that can manage such tradeoffs is a very large task and the Brazilian PT has only partially achieved it. 
${ }^{1}$ Khagram, Sanjeev. 2004. Dams and Development: Transnational Struggles for Water and Power. Ithaca: Cornell University Press, page 142.

${ }^{2}$ Hochstetler, Kathryn and Margaret E. Keck. 2007. Greening Brazil: Environmental Activism in State and Society. Durham: Duke University Press. Socioenvironmentalism is a Brazilian term for the conjuncture of environmental concerns and social ones, like impacts on local communities.

${ }^{3}$ Weyland, Kurt, Raúl L. Madrid, and Wendy Hunter, eds. 2010. Leftist Governments in Latin America: Successes and Shortcomings. Cambridge: Cambridge University Press. ${ }^{4}$ Evans, Peter B. and Patrick Heller. 2015. Human Development, State Transformation and the Politics of the Developmental State. In The Oxford Handbook of Transformations of the State, edited by Stephan Leibfried, Evelyne Huber, Matthew Lange, Jonah D. Levy, Frank Nullmeier, and John D. Stephens. Oxford: Oxford University Press, pages 679-701.

${ }^{5}$ Edigheji, Omano, ed. 2010. Constructing a Democratic Developmental State in South Africa: Potentials and Challenges. Cape Town: HSRC Press; Evans and Heller 2015, pages 681-684; Robinson, Mark and Gordon White, eds. 1998. The Democratic Developmental State: Political and Institutional Design. Oxford: Oxford University Press; Swilling, Mark and Eve Annecke. 2012. Just Transitions: Explorations of Sustainability in an Unfair World. Claremont: University of Cape Town Press.

${ }^{6}$ Glasson, John, Riki Therivel, and Andrew Chadwick. 2012. Introduction to Environmental Impact Assessment, $4^{\text {th }}$ Edition. London and New York: Routledge. 
${ }^{7}$ Fox, Jonathan A. and L. David Brown, eds. 1998. The Struggle for Accountability: The World Bank, NGOs, and Grassroots Movements. Cambridge, MA: The MIT Press; Keck, Margaret E. and Kathryn Sikkink. 1998. Activists Beyond Borders: Advocacy Networks in International Politics. Ithaca: Cornell University Press.

${ }^{8}$ Hochstetler and Keck 2007.

${ }^{9}$ Altshuler, Alan and David Luberoff. 2003. Mega-Projects: The Changing Politics of Urban Public Investment. Washington, DC: Brookings Institution; McAdam, Doug and Hilary Schaffer Boudet. 2012. Putting Social Movements in Their Place: Explaining Opposition to Energy Projects in the United States, 2000-2005. Cambridge: Cambridge University Press. As this article will show, this is also true in Brazil.

${ }^{10}$ Bratman, Eve Z. 2014. Contradiction of Green Development: Human Rights and Environmental Norms in Light of Belo Monte Dam Activism. Journal of Latin American Studies 46(2): 261-289; Fearnside, Philip. 2006. Dams in the Amazon: Belo Monte and Brazil's Hydroelectric Development of the Xingu River Basin. Environmental Management 38(1): 16-27; Hochstetler, Kathryn. 2011. The Politics of Environmental Licensing: Energy Projects of the Past and Future in Brazil. Studies in Comparative International Development 46(4): 349-371; McCormick, Sabrina. 2009. Mobilizing Science: Movements, Participation and the Remaking of Knowledge. Philadelphia: Temple University Press.

${ }^{11}$ We constructed this dataset through a Freedom of Information request to the bank and through the bank's press releases, online at http://www.bndes.gov.br/SiteBNDES/bndes/bndes_pt/Institucional/Sala_de_Imprensa/. Details are below. 
${ }^{12}$ Johnson, Chalmers. 1982. MITI and the Japanese Miracle. Stanford: Stanford

University Press; Leftwich, Adrian. 1995. Bringing Politics Back In: Towards a Model of the Developmental State. Journal of Development Studies 31(3): 400-427; Woo-

Cumings, Meredith, ed. 1999. The Developmental State. Ithaca: Cornell University Press.

${ }^{13}$ Johnson 1982, pages 17-22; Kohli, Atul. 2004. State-Directed Development: Political

Power and Industrialization in the Global Periphery. Cambridge: Cambridge University

Press, page 10; Wade, Robert. 1990. Governing the Market: Economic Theory and the

Role of Government in East Asian Industrialization. Princeton: Princeton University

Press.

${ }^{14}$ Altschuler and Luberoff 2003; Fox, Jonathan. 2007. Accountability Politics: Power and Voice in Rural Mexico. Oxford: Oxford University Press.

${ }^{15}$ Evans, Peter. 1979. Dependent Development: The Alliance of Multinational, State, and Local Capital in Brazil. Princeton: Princeton University Press; Sikkink, Kathryn. 1991. Ideas and Institutions: Developmentalism in Brazil and Argentina. Ithaca: Cornell University Press.

${ }^{16}$ Ban, Cornel. 2013. Brazil's Liberal Neo-developmentalism: New Paradigm or Edited Orthodoxy? Review of International Political Economy 20(2): 298-331; Bresser-Pereira, Luiz Carlos. 2003. Desenvolvimento e Crise no Brasil: História, Economia e Política de Getúlio Vargas a Lula, $5^{\text {th }}$ Ed. São Paulo: Editora 34; Bresser-Pereira, Luiz Carlos. 2009. Developing Brazil: Overcoming the Failure of the Washington Consensus. Boulder: Lynne Rienner; Hochstetler, Kathryn and Alfred P. Montero. 2013. The Renewed Developmental State: The National Development Bank and the Brazil Model. Journal of Development Studies 49(11): 1484-1499. 
${ }^{17}$ Ban 2013, pages 305-306; Hochstetler and Montero 2013, pages 1490-1491.

${ }^{18}$ Bresser-Pereira 2009, page 250; Dréze, Jean and Amartya Sen 2012. India:

Development and Participation. Oxford: Oxford University press, pages 38-41; Evans and Heller 2015, page 683.

${ }^{19}$ Evans and Heller 2015, pages 681-683; Evans, Peter B. 2010. Constructing the $21^{\text {st }}$ Century Developmental State. In Constructing a Democratic Developmental State in South Africa: Potentials and Challenges, ed. O. Edigheji. Cape Town: HSRC Press, pages 37-59; Evans, Peter B. 1995. Embedded Autonomy: States and Industrial Transformation. Princeton: Princeton University Press.

${ }^{20}$ Edigheji 2010; Robinson and White 1998; Swilling and Annecke 2012.

${ }^{21}$ On environmental protection, see Dréze and Sen 2002, pages 62-63; Swilling and Anneke 2012.

${ }^{22}$ Evans and Heller 2015, page 683.

${ }^{23}$ Jenkins, Rhys, ed. 2000. Industry and Environment in Latin America. London: Routledge.

${ }^{24}$ Hochstetler, Kathryn and Genia Kostka. 2015. Wind and Solar Power in Brazil and China: Interests, State-Business Relations, and Policy Outcomes. Global Environmental Politics 15(3): 75-94.

${ }^{25}$ Morgan, Richard K. 2012. Environmental Impact Assessment: The State of the Art. Impact Assessment and Project Appraisal 30(1): 5-14.

${ }^{26}$ Dubash, Navroz and Bronwen Morgan, eds. 2013. The Rise of the Regulatory State of the South: Infrastructure and Development in Emerging Economies. Oxford: Oxford University Press. 
${ }^{27}$ Pekkanen, Robert. 2004. After the Developmental State: Civil Society in Japan. Journal of East Asian Studies 4: 363-388; Wade 1990, page 29.

${ }^{28}$ Kohli 2004, pages 10-11; Wade 1990.

${ }^{29}$ Baiocchi, Gianpaolo, Patrick Heller, and Marcelo K. Silva. 2011. Bootstrapping Democracy: Transforming Local Governance and Civil Society in Brazil. Stanford:

Stanford University Press.

${ }^{30}$ Baiocchi, Heller, and Silva 2011; Edigheji 2010; Robinson and White 1999; Swilling and Annecke 2012. For a much more pessimistic view, see Zhouri, Andréa and Norma Valencio, eds. 2014. Formas de Matar, de Morrer e de Resistir: Limites da Resolução Negociada de Conflitos Ambientais. Belo Horizonte: Editora UFMG.

${ }^{31}$ Aldrich, Daniel P. 2008. Site Fights: Divisive Facilities and Civil Society in Japan and the West. Ithaca: Cornell University Press; McAdam and Boudet 2012; Sherman, Daniel J. 2011. Not Here, Not There, Not Anywhere: Politics, Social Movements, and the Disposal of Low-Level Radioactive Waste. Washington, DC: Resources for the Future Press.

${ }^{32}$ Bratman 2014; Khagram 2004; McCormick 2009; Sherman 2011; Zhouri and Valencio 2014.

${ }^{33}$ McAdam and Boudet 2012.

${ }^{34}$ McAllister, Lesley K. 2008. Making Law Matter: Environmental Protection and Legal Institutions in Brazil. Stanford: Stanford Law Books.

${ }^{35}$ Ministério de Minas e Energia. 2007. Plano Nacional de Energia 2030. Brasília: Ministério de Minas e Energia, Empresa de Pesquisa Energética.

${ }^{36}$ World Bank Group. 2009. Directions in Hydropower. Washington, DC: The World 
Bank.

${ }^{37}$ Aldrich 2008.

${ }^{38}$ Hochstetler 2011.

${ }^{39}$ Meyer, David S. and Debra C. Minkoff. 2004. Conceptualizing Political Opportunity. Social Forces 82(4): 1457-1492.

${ }^{40}$ McAllister 2008.

${ }^{41}$ Wright, Rachel A. and Hilary Schaffer Boudet. 2012. To Act or Not to Act: Context, Capability, and Community Responses to Environmental Risk. American Journal of Sociology 118(3), pages 746-747.

${ }^{42}$ Acselrad, Henri, Selene Herculano, and José Augusto Pádua, eds. 2004. Justiça Ambiental e Cidadania. Rio de Janeiro: Relume Dumará; Aldrich 2008; Zhouri and Valencio 2014.

${ }^{43}$ Oliveira, Edilson de. 2007. Political Economy of the Brazilian Power Industry Reform. In The Political Economy of Power Sector Reform: The Experiences of Five Major Developing Countries, eds. D. Victor and T.C. Heller. Cambridge: Cambridge University Press.

${ }^{44}$ For example, Ministério de Minas e Energia. 2006. Balanço Energético Nacional 2006: Ano Base 2005. Rio de Janeiro: Ministério de Minas e Energia, Empresa de Pesquisa Energética.

${ }^{45}$ For example, Ministério de Minas e Energia 2007.

${ }^{46}$ Interview with analyst of the Empresa de Pesquisa Energética, Rio de Janeiro, June, 2012.

${ }^{47}$ Interviews with analysts of the Empresa de Pesquisa Energética, Rio de Janeiro, June, 
2009 and June, 2012.

${ }^{48}$ Hochstetler and Kostka 2015.

${ }^{49}$ http://www.brasil.gov.br/pac/o-pac/investimentos-em-infraestrutura-para-odesenvolvimento-economico-e-social.

${ }^{50}$ Interview with Celso Knijnik, Director of the Energy Program of the PAC, Ministério de Planejamento, Brasília, September 2014; Interview with Alessandra de Toledo, former Coordinator of Electricity, Nuclear Energy, and Pipelines, IBAMA, Brasília, September 2014.

${ }^{51}$ Sikkink 1991.

${ }^{52}$ Hochstetler and Montero 2013.

${ }^{53}$ Interview with five current and former members of the BNDES Structuration of Loans and Infrastructure divisions, Rio de Janeiro, June, 2012.

${ }^{54}$ Interview with two officials of civil society network RedeBrasil, Brasília, June, 2009; Interview with official of the Movimento dos Atingidos por Barragens (MAB), São Paulo, November, 2013. See also RedeBrasil sobre Instituições Financeiras Multilaterais. 2007. O BNDES que Temos e que Queremos: O Papel do BNDES no Financiamento do Desenvolvimento Nacional Democrático. São Paulo: Editora Expressão Popular; Zhouri and Valencio 2014.

55 Telephone interview with Sérgio Weguelin, then-Superintendent of the Environment Area, BNDES, Rio de Janeiro, July 2011.

${ }^{56}$ Hochstetler and Keck 2007; Landim, Stephanie N.T. and Luis E. Sánchez. 2012. The Contents and Scope of Environmental Impact Statements: How Do They Evolve Over Time? Impact Assessment and Project Appraisal 30, 217-228. 
${ }^{57}$ Law 7,804/1989, further detailed by Complementary Law 140/2011.

${ }^{58}$ World Bank. 2008. Environmental Licensing for Hydroelectric Projects in Brazil: A Contribution to the Debate, Volume 1: Summary Report. Washington, DC: Work Bank, Brazil Country Management Unit, Report No. 40995-BR, page 10. We describe in more detail below how we count these and other challenges.

${ }^{59}$ Interview with Toledo 2014; Bratman 2014; Hochstetler 2011; Zhouri and Valencio 2014.

${ }^{60}$ McAllister 2008, page 155.

${ }^{61}$ McAllister 2008, pages 98-99.

${ }^{62}$ Bratman 2014; Hochstetler 2011.

${ }^{63}$ Interview with Knijnik, 2014.

${ }^{64}$ Interview with official of MAB 2013.

${ }^{65}$ Interview with IBASE representative, Rio de Janeiro, August, 2005; Hochstetler and Keck, pages 216-221.

${ }^{66}$ The press releases are online at http://www.bndes.gov.br/SiteBNDES/bndes/bndes_pt/Institucional/Sala_de_Imprensa/. ${ }^{67}$ Earl, Jennifer, Andrew Martin, John D. McCarthy, and Sarah A. Soule. 2004. The Use of Newspaper Data in the Study of Collective Action. Annual Review of Sociology 30: $65-80$.

${ }^{68}$ Oliveira 2007.

${ }^{69}$ Bakken, Tor Haakon, Hakon Sundt, Audun Ruud, and Atle Harby. 2012. Development of Small versus Large Hydropower in Norway: Comparison of Environmental Impacts. Energy Procedia 20: 185-199. 
${ }^{70}$ Meyer and Minkoff 2004.

${ }^{71}$ Ferraz, Claudio. 2007. Electoral Politics and Bureaucratic Discretion: Evidence from Environmental Licenses and Local Elections in Brazil. Rio de Janeiro: Instituto de Pesquisa Econômica Aplicada, manuscript.

72 Boas, Taylor C., F. Daniel Hidalgo, and Neal P. Richardson. 2014. The Spoils of Victory: Campaign Donations and Government Contracts in Brazil. Journal of Politics 76(2): 415-429. The website http://www.asclaras.org.br/@busca_global.php includes detailed information on donations by individual firms to candidates for elections at all levels in Brazil from 2002-2012. We searched for donations from the firms receiving loans to build electricity projects to candidates running for office in the municipalities and states of the projects in the elections immediately before and after the project began and found too few for analysis.

${ }^{73}$ Samuels, David. 2006. Sources of Mass Partisanship in Brazil. Latin American Politics and Society 48(2): 1-27.

${ }^{74}$ Levy, Charmain. 2012. Social Movements and Political Parties in Brazil: Expanding Democracy, the "Struggle for the Possible" and the Reproduction of Power Structures. Globalisations 9(6): 783-798.

${ }^{75}$ www.tse.jus.br/eleicoes/eleicoes-anteriores

${ }^{76}$ Wright and Boudet 2012.

${ }^{77}$ Acselrad, Herculano, and Pádua 2003; Aldrich 2008.

${ }^{78}$ www.cidades.ibge.gov.br. GDP per capita data was only available for 2011 , based on the 2010 census. GDP data was available on an annual basis, but did not produce substantially different results. HDI was measured at the municipal level in 2000 and 
2010. The 2000 HDI figure was used for projects in 2002-2003, the 2010 figure was used for 2008-2012, and an average of the two was used for 2004-2007. We are grateful to Mike Touchton and Brian Wampler for providing data on NGOs per municipality in 2002 and 2005 .

${ }^{79}$ Hochstetler 2011; McAdam and Boudet 2012.

${ }^{80}$ Bratman 2014; Hochstetler and Keck 2007, pages 18-20; Hochstetler 2011.

${ }^{81}$ See also Baiocchi, Heller, and Silva 2011.

${ }^{82}$ Interview with representative of the Movimento dos Atingidos por Barragens, São Paulo, November, 2013.

${ }^{83}$ Altshuler and Luberoff 2003.

${ }^{84}$ Very little of the secondary literature cited covers such cases in detail, allowing for very different interpretations. Baiocchi, Heller, and Silva (2011) see a positive context of consultation and participation, while Zhouri and Valencio (2014) title their work "Forms of Killing, Dying, and Resisting” (translated). See also Landim and Sánchez 2012.

${ }^{85}$ Interview EPE 2012.

${ }^{86}$ Edigheji 2010; Swilling and Annecke 2012. 